\title{
Candesartan and amlodipine combination therapy provides powerful vascular protection in stroke-prone spontaneously hypertensive rats
}

\author{
Shinji Takai ${ }^{1}$, Denan Jin ${ }^{1}$, Takashi Shimosato ${ }^{2}$, Hiroshi Sakonjo ${ }^{1,2}$ and Mizuo Miyazaki ${ }^{1}$
}

The vascular protective effects of placebo, candesartan ( $1 \mathrm{mg} \mathrm{kg}^{-1}$ per day) monotherapy, candesartan ( $1 \mathrm{mg} \mathrm{kg}^{-1}$ per day) and amlodipine ( $1 \mathrm{mg} \mathrm{kg}^{-1}$ per day) combination therapy, and candesartan ( $1 \mathrm{mg} \mathrm{kg}^{-1}$ per day) and hydrochlorothiazide (HCTZ) $\left(10 \mathrm{mg} \mathrm{kg}^{-1}\right.$ per day) combination therapy for 2 weeks were compared in stroke-prone, spontaneously hypertensive rats. Candesartan monotherapy significantly reduced blood pressure, and both combination therapies were equally and significantly lower than the monotherapy. Acetylcholine-induced vascular relaxation was significantly stronger in all therapeutic groups than in the placebo-treated group. Furthermore, the relaxation was significantly stronger in the candesartan plus amlodipine-treated group than in the candesartan-treated group; however, there was no significant difference between the candesartan- and candesartan plus HCTZ-treated groups. Vascular gene expressions of the NADPH oxidase subunits 222 $^{\text {phox }}$, gp9 $1^{\text {phox }}$, NOX1 and NOX4 were significantly attenuated in all therapeutic groups compared with the placebo-treated group, and there were no significant differences among those groups. However, a significant augmentation of vascular superoxide dismutase activity was observed in the candesartan plus amlodipine-treated group, but not in other groups. Malondialdehyde levels in the vascular tissues were significantly attenuated in all therapeutic groups. Compared with the candesartan-treated group, significant attenuation was observed in the candesartan plus amlodipine-treated group, but not in the candesartan plus HCTZ-treated group. Immunohistological analysis showed that areas positive for 4-hydroxy-2-nonenal were significantly reduced in all therapeutic groups, but this reduction was significantly greater for the candesartan plus amlodipine-treated group than for the candesartantreated group. Thus, candesartan and amlodipine combination therapy could have a powerful protective effect in vascular tissues via the reduction of oxidative stress.

Hypertension Research (2011) 34, 245-252; doi:10.1038/hr.2010.224; published online 25 November 2010

Keywords: angiotensin II receptor blocker; $\mathrm{AT}_{1}$ receptor; NADPH oxidase; oxidative stress; vascular function

\section{INTRODUCTION}

Angiotensin II has an important role in increasing blood pressure by stimulating angiotensin II type 1 receptors. Stimulation of these receptors by angiotensin II also induces oxidative stress by activating NADPH oxidase, which results in the augmentation of vascular dysfunction. ${ }^{1-3}$ Therefore, by blocking the binding of angiotensin II to angiotensin II type 1 receptors, angiotensin II receptor blockers (ARBs) not only reduce blood pressure, but they also have a powerful vascular protective effect. ${ }^{4,5}$ On the other hand, angiotensin-converting enzyme (ACE) inhibitors, which work by inhibiting angiotensin II formation, have also been widely used in the clinical setting. Both ACE inhibitors and ARBs have shown greater ability to prevent organ damage than other antihypertensive drugs in clinical studies. ${ }^{6,7}$ However, the degree of blood pressure decrease has also been shown to affect organ protection in hypertensive patients. ${ }^{8,9}$ The Japanese Society of Hypertension's Guidelines for the Management of
Hypertension (JSH 2009) recommends combining ARBs with calcium channel blockers (CCBs) or diuretics to lower blood pressure. ${ }^{10}$ In the Anglo-Scandinavian Cardiac Outcomes Trial-Blood Pressure Lowering Arm, ACE inhibitor and CCB combination therapy inhibit strokes more effectively than $\beta$-blocker and diuretic combination therapy. ${ }^{11}$ In the Losartan Intervention For Endpoint reduction in hypertension study, cardiovascular events also appeared to occur less often with a combination of ARB and diuretic therapy than with $\beta$-blocker and diuretic combination therapy. ${ }^{12}$ Thus, the usefulness of combining a renin-angiotensin system inhibitor with a CCB or a renin-angiotensin system inhibitor with a diuretic has been shown in clinical studies.

In Dahl salt-sensitive rats, $\mathrm{ARB}$ and $\mathrm{CCB}$ combination therapy has been shown to have a significantly greater preventive effect on cardiac fibrosis than ARB monotherapy, although no additional blood pressure-lowering effect was observed with combination therapy compared with monotherapy. ${ }^{13}$ In mice, $\mathrm{ARB}$ and $\mathrm{CCB}$ combination

${ }^{1}$ Department of Pharmacology, Osaka Medical College, 2-7 Daigaku-cho, Takatsuki City, Osaka, Japan and 2Shiga Research Center, Nissei BILIS, 555 Ukawa, Koka City, Shiga, Japan

Correspondence: Dr S Takai, Department of Pharmacology, Osaka Medical College, 2-7 Daigaku-machi, Takatsuki City, Osaka 569-8686, Japan.

E-mail: pha010@art.osaka-med.ac.jp

Received 10 June 2010; revised 15 August 2010; accepted 16 August 2010; published online 25 November 2010 
therapy was more effective than ARB monotherapy for preventing vascular proliferation in cuff-injured arteries, although the two treatments showed no significant difference in blood pressure-lowering ability. ${ }^{14}$ In a recent study, ARB and CCB combination therapy was more effective in preventing cuff-induced vascular proliferation in mice than both $\mathrm{ARB}$ monotherapy and $\mathrm{ARB}$ and diuretic combination therapy, despite providing no significant lowering of blood pressure. ${ }^{15}$ These findings suggest the usefulness of $\mathrm{ARB}$ and $\mathrm{CCB}$ combination therapy, despite the absence of blood pressure reduction. However, it has been unclear which of the combination therapy, ARB plus CCB or ARB plus diuretic, is more useful for preventing vascular dysfunction because both combination therapies cause an additional hypotensive effect compared with monotherapy.

In the present study, we evaluated the vascular protective effects of candesartan $\left(1 \mathrm{mg} \mathrm{kg}^{-1}\right.$ per day, a dose that produces a significant hypotensive effect) as an ARB monotherapy as well as the combination therapies candesartan $\left(1 \mathrm{mg} \mathrm{kg}^{-1}\right.$ per day) plus amlodipine ( $1 \mathrm{mg} \mathrm{kg}^{-1}$ per day) and candesartan $\left(1 \mathrm{mg} \mathrm{kg}^{-1}\right.$ per day) plus hydrochlorothiazide (HCTZ) ( $10 \mathrm{mg} \mathrm{kg}^{-1}$ per day). The doses for each combination therapy produced significantly greater hypotensive effects than ARB monotherapy in a preliminary study of stroke-prone spontaneously hypertensive rats (SHR-SP).

\section{METHODS}

\section{Animals}

Eight-week-old male Wistar-Kyoto (WKY) rats and SHR-SP were obtained from Japan SLC (Shizuoka, Japan). All rats were given normal rat chow (F-2, Funabashi Farm, Chiba, Japan). The experiments were conducted in accordance with the Guide for the Care and Use of Laboratory Animals (Animal Research Laboratory, Osaka Medical College, Osaka, Japan).

The SHR-SP were orally administered either a placebo $(n=6)$; candesartan ( $1 \mathrm{mg} \mathrm{kg}^{-1}$ per day) $(n=6)$, candesartan $\left(1 \mathrm{mg} \mathrm{kg}^{-1}\right.$ per day) plus amlodipine $\left(1 \mathrm{mg} \mathrm{kg}^{-1}\right.$ per day) $(n=6)$, or candesartan $\left(1 \mathrm{mg} \mathrm{kg}^{-1}\right.$ per day) plus HCTZ ( $10 \mathrm{mg} \mathrm{kg}^{-1}$ per day) $(n=6)$ by gavage for 2 weeks. The SHR-SP placebotreated group received the same volume of water as the other groups received of vehicle. Systolic blood pressure (SBP) was monitored by tail-cuff plethysmography (BP-98, Softron, Tokyo, Japan) 1 and 2 weeks after the beginning of treatment. WKY rats were used as a normal control. Two weeks after the beginning of the treatment, the rats were anesthetized with $35 \mathrm{mg} \mathrm{kg}^{-1}$ of sodium pentobarbital to obtain blood and tissues.

\section{Renin activity, ACE activity and angiotensin II concentration in blood}

Plasma was separated from the blood samples by centrifugation at $3000 \mathrm{~g}$ for $15 \mathrm{~min}$ at $4{ }^{\circ} \mathrm{C}$. Plasma renin activity (PRA) was determined using an SRL renin kit (TFB, Tokyo, Japan).

Serum ACE activity was measured by incubating the plasma for $30 \mathrm{~min}$ at $37^{\circ} \mathrm{C}$ with $5 \mathrm{mmoll}^{-1}$ of hippuryl-His-Leu (Peptide Institute, Osaka, Japan) as the substrate in $100 \mathrm{mmoll}^{-1}$ of phosphate buffer ( $\mathrm{pH}$ 8.3) containing $300 \mathrm{mmoll}^{-1} \mathrm{NaCl}^{16}$ One unit of ACE activity was defined as the amount of enzyme required to cleave $1 \mu \mathrm{mol}$ of hippuric acid $\min ^{-1} .16$

Serum angiotensin II concentrations were measured using an enzyme immunoassay kit (Peninsula Laboratories, Belmont, CA, USA).

Acetylcholine-induced vascular relaxation in the isolated rat artery To measure the gene expression and activities of several parameters of the aorta, we immediately froze specimens for enzymatic assessment, and the remaining aorta was fixed for histological assessment. In a previous report, acetylcholineinduced vascular responses in SHR-SP, including acetylcholine-induced vascular relaxation, were the same for the carotid artery and the aorta. ${ }^{18}$ Therefore, we used the carotid arteries to evaluate acetylcholine-induced vascular relaxation. Isolated rat carotid arteries were cut into $10 \times 1.0 \mathrm{~mm}$ helical strips and placed on a myograph with a resting tension of $1.0 \mathrm{~g}$ in Tyrode's solution $\left(137 \mathrm{mmoll}^{-1} \mathrm{NaCl}, 2.7 \mathrm{mmoll}^{-1} \mathrm{KCl}, 1.8 \mathrm{mmoll}^{-1} \mathrm{CaCl}_{2}, 1.1 \mathrm{mmoll}^{-1}\right.$
$\mathrm{MgCl}_{2}, 0.42 \mathrm{mmoll}^{-1} \mathrm{NaH}_{2} \mathrm{PO}_{4}, 12 \mathrm{mmoll}^{-1} \mathrm{NaHCO}_{3}$ and $5.7 \mathrm{mmoll}^{-1}$ glucose, $\mathrm{pH} 7.4$ ) at $37^{\circ} \mathrm{C}$ and continuously bubbled with $5 \% \mathrm{CO}_{2}$ in $\mathrm{O}_{2}{ }^{4,17}$ The strips were vasoconstricted with $50 \mathrm{mmoll}^{-1} \mathrm{KCl}$ and then washed. Acetylcholine-induced relaxation was assessed after contraction to a steady state tension using $1 \mu \mathrm{moll}^{-1}$ norepinephrine. In the present study, we used $0.1 \mu \mathrm{moll}^{-1}$ of acetylcholine, which shows a maximum response between 50 and $80 \%$ after contraction to a steady state tension using $1 \mu \mathrm{moll}^{-1}$ norepinephrine, as in our previous studies. ${ }^{4,17}$ These responses provided an easy method for evaluating the differences among the agents.

\section{Real-time PCR}

The total RNA $(1 \mu \mathrm{g})$ of the aorta was transcribed into cDNA with Superscript III reverse transcriptase and random hexamers (Invitrogen, Carlsbad, CA, USA). ${ }^{5}$ The mRNA was measured by Real-time PCR on a LightCycler with Roche Diagnostics software (Tokyo, Japan) using TaqMan fluorogenic probes. All primers and probes for Real-time PCR of endothelial nitric oxide synthase (eNOS), p22 $2^{\text {phox }}$, gp91 $1^{\text {phox }}$, NOX1, NOX4, copper/zinc-containing SOD, manganese superoxide dismutase (Mn-SOD), extracellular SOD and ACE were designed by Roche Diagnostics.

\section{Immunohistochemistry}

Fixed aortic tissues were embedded in paraffin, and each block was cut into $3-\mu \mathrm{m}$-thick sections. The sections were incubated with $3 \% \mathrm{H}_{2} \mathrm{O}_{2}$ in methanol to inhibit endogenous peroxidase and then incubated with protein-blocking solution (Dako, Tokyo, Japan) to block non-specific antigens. The sections were incubated with mouse anti-4-hydroxy-2-nonenal (4-HNE) antibody (Nikken Seil, Shizuoka, Japan). ${ }^{5}$ A secondary biotinylated anti-IgG antibody (Invitrogen) was used. Sections were visualized using horseradish peroxidase and 3-amino-9-ethylcarbozole as the substrate chromogen (Dako). The nuclei were counterstained with hematoxylin. The immunostain-positive area was quantified with an image analysis system (Model VM-30, Olympus Optical, Tokyo, Japan).

\section{Vascular enzyme activities and malondialdehyde (MDA) levels}

The remaining aortic tissue was homogenized in $20 \mathrm{mmoll}^{-1}$ Na-phosphate buffer, $\mathrm{pH}$ 7.4. ${ }^{16}$ The homogenate was centrifuged at $15000 \mathrm{~g}$ for $30 \mathrm{~min}$. The supernatant was discarded, and the pellet was resuspended and homogenized in $10 \mathrm{mmoll}^{-1} \mathrm{Na}$-phosphate buffer, pH 7.4, containing $2 \mathrm{moll}^{-1} \mathrm{KCl}$ and $0.1 \%$ Nonidet P-40. The homogenate was centrifuged at $15000 \mathrm{~g}$ for $30 \mathrm{~min}$, and the supernatant was used for measurements of enzyme activities and MDA levels.

Vascular ACE activity was measured by incubating tissue extracts for $1 \mathrm{~h}$ at $37^{\circ} \mathrm{C}$, with $5 \mathrm{mmoll}^{-1}$ of hippuryl-His-Leu (Peptide Institute) as the substrate in $100 \mathrm{mmoll}^{-1}$ of phosphate buffer ( $\mathrm{pH} 8.3$ ) containing $300 \mathrm{mmoll}^{-1} \mathrm{NaCl}^{16}$ One unit of ACE activity was defined as the amount of enzyme required to cleave $1 \mu \mathrm{mol}$ of hippuric acid $\mathrm{min}^{-1}$.

Vascular SOD activity was measured using a Superoxide Dismutase Assay kit (Cayman Chemical Company, Ann Arbor, MI, USA).

$\mathrm{MDA}$, which is a product of lipid peroxidation in tissue extracts, was measured by incubating tissue extracts for $1 \mathrm{~h}$ at $60^{\circ} \mathrm{C}$ with $20 \mathrm{mmoll}^{-1}$ thiobarbituric acid in $0.3 \mathrm{mmoll}^{-1}$ phosphoric acid. ${ }^{16}$ The reaction was terminated by cooling on ice, and the mixture was then centrifuged at $15000 \mathrm{~g}$ for $5 \mathrm{~min}$ at $4^{\circ} \mathrm{C}$. The absorbance of the supernatant was recorded at $532 \mathrm{~nm}$.

Protein concentration was assayed with BCA Protein Assay Reagents (Pierce, Rockford, IL, USA) using bovine serum albumin as a standard.

\section{Statistical analysis}

Data are expressed as means \pm s.e.m. Statistical analyses were performed using a parametric test with Fisher's protected least significant difference. Differences were considered significant when the $P$ value was $<0.05$.

\section{RESULTS}

\section{Blood pressure in SHR-SP}

In SHR-SP, the SBPs before the administration of placebo, candesartan, candesartan plusamlodipine and candesartan plus HCTZ were $181 \pm 5.1,181 \pm 4.4,182 \pm 2.7$ and $182 \pm 2.7 \mathrm{~mm} \mathrm{Hg}$, respectively; in the age-matched WKY rats, SBP was $119 \pm 2.0 \mathrm{~mm} \mathrm{Hg}$ (Figure 1). 
SBP was $236 \pm 4.1 \mathrm{~mm} \mathrm{Hg}$ after the final placebo treatment, but it significantly decreased to $186 \pm 2.0 \mathrm{~mm} \mathrm{Hg}$ after candesartan treatment. The SBPs in the candesartan plus amlodipine- and candesartan plus HCTZ-treated groups were $155 \pm 5.8$ and $150 \pm 3.6 \mathrm{~mm} \mathrm{Hg}$, respectively; both were significantly lower than in the placebo- and candesartan-treated groups.

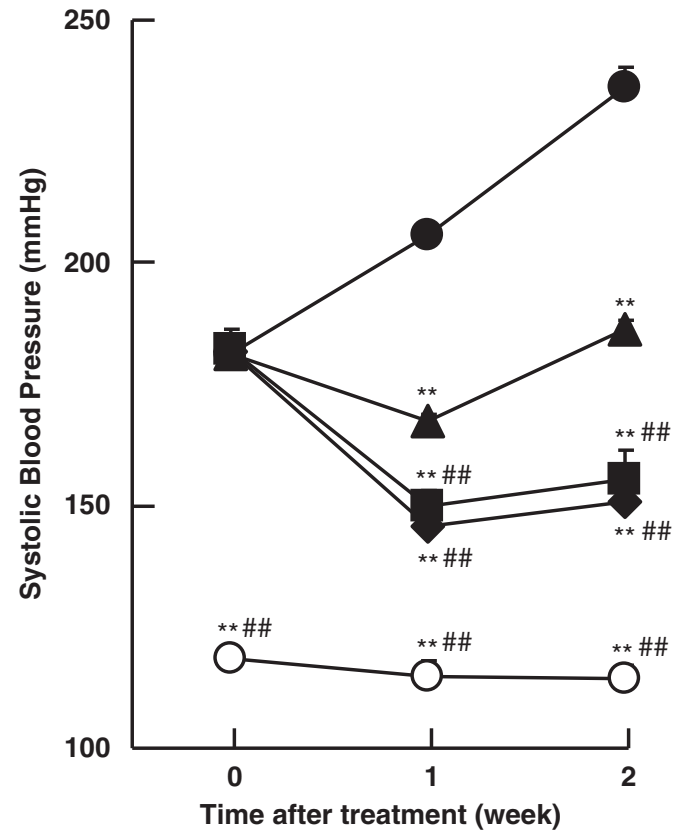

Figure 1 Systolic blood pressure in Wistar-Kyoto (WKY) rats (open circles) and placebo (closed circles)-, candesartan (closed triangles)-, candesartan plus amlodipine (closed squares)- and candesartan plus hydrochlorothiazide (HCTZ) (closed diamonds)-treated stroke-prone spontaneously hypertensive rats (SHR-SP) at 0,1 and 2 weeks after starting treatment. ${ }^{* *} P<0.01$ vs. placebo-treated SHR-SP. ${ }^{\#} P<0.01$ vs. candesartan-treated SHR-SP.

\section{Body weight and heart weight}

Body weight, heart weight and the ratio of heart weight to body weight are shown in Table 1. The WKY rats were heavier, but there were no significant differences among the SHR-SP groups. The hearts of the placebo-treated SHR-SP tended to be heavier than those of the WKY rats, but the differences were not significant. The hearts weighed significantly less in both the candesartan plus amlodipine- and the candesartan plus HCTZ-treated groups than in the placebo-treated group, but there was no significant difference between the combination-therapy groups.

The ratio of heart weight to body weight was significantly higher in the placebo-treated SHR-SP than in the WKY rats. The ratio was significantly lower in both the candesartan plus amlodipine- and candesartan plus HCTZ-treated groups than in the placebo-treated group, but the differences were not significant.

PRA, serum ACE activity and serum angiotensin II concentration PRA, serum ACE activity and serum angiotensin II concentration after the last treatment are shown in Table 2. PRA was similar in the WKY rats and the placebo-treated SHR-SP. PRA was significantly higher in the candesartan-, candesartan plus amlodipine- and candesartan plus HCTZ-treated groups than in the placebo-treated group, but the differences among the treatment groups were not significant.

Serum ACE activity was significantly lower in the placebo-treated SHR-SP than in the WKY rats, but no significant differences were observed among the placebo-, candesartan-, candesartan plus amlodipine- and candesartan plus HCTZ-treated SHR-SP.

The serum angiotensin II concentration was not significantly different between the WKY rats and the placebo-treated SHR-SP. Like PRA concentrations, serum angiotensin II concentrations were also significantly higher in the candesartan-, candesartan plus amlodipine- and candesartan plus HCTZ-treated groups than in the placebo-treated group, but the differences among these groups were not significant.

\section{Vascular relaxation and eNOS gene expression}

In all rats, acetylcholine-induced vascular relaxation was assessed as an index of endothelial function (Figure 2a). Vascular relaxation was

Table 1 Body weight, heart weight and ratio of heart weight to body weight

SHR-SP

\begin{tabular}{|c|c|c|c|c|c|}
\hline Parameters & $W K Y$ rats $(\mathrm{n}=6)$ & Placebo $(\mathrm{n}=6)$ & Candesartan $(\mathrm{n}=6)$ & Candesartan +amlodipine $(\mathrm{n}=6)$ & Candesartan + HCTZ $(\mathrm{n}=6$ \\
\hline Body weight (g) & $257 \pm 4.5^{* *}$ & $207 \pm 4.1$ & $208 \pm 3.8$ & $204 \pm 2.7$ & $198 \pm 2.5$ \\
\hline Heart weight (mg) & $775 \pm 23$ & $833 \pm 35$ & $790 \pm 19$ & $742 \pm 18 * *$ & $717 \pm 23^{* *}$ \\
\hline Heart weight/body weight $\left(\mathrm{mgg} \mathrm{g}^{-1}\right)$ & $3.02 \pm 0.11^{* *}$ & $4.01 \pm 0.11$ & $3.79 \pm 0.08$ & $3.63 \pm 0.06 * *$ & $3.62 \pm 0.09 * *$ \\
\hline
\end{tabular}

Abbreviations: HCTZ, hydrochlorothiazide; SHR-SP, stroke-prone spontaneously hypertensive rats; WKY, Wistar-Kyoto.

Values are mean \pm s.e.m. ${ }^{* *} P<0.01$ vs. placebo. ${ }^{\#} P<0.05$ vs. candesartan.

Table 2 PRA, serum ACE activity and serum angiotensin II concentration

SHR-SP

WKY rats $(\mathrm{n}=6) \quad$ Placebo $(\mathrm{n}=6) \quad$ Candesartan $(\mathrm{n}=6)$

Candesartan+amlodipine $(\mathrm{n}=6)$

Candesartan+HCTZ $(\mathrm{n}=6)$

PRA (ng Al ml ${ }^{-1}$ per h)

Serum ACE activity ( $\mathrm{mU} \mathrm{ml}^{-1}$ )

$6.0 \pm 0.6$

$95.0 \pm 4.9 * *$

$5.9 \pm 1.0$

$40.3 \pm 2.7$

$15.9 \pm 1.5^{* *}$

$38.0 \pm 1.2$

$123 \pm 11$ **
$13.3 \pm 2.4$ **
$34.7 \pm 1.4$

$108 \pm 25^{* *}$
$17.1 \pm 0.8^{* *}$

$39.0 \pm 1.1$

$150 \pm 21$ **

Abbreviations: ACE, angiotensin-converting enzyme; PRA, Plasma renin activity; HCTZ, hydrochlorothiazide; SHR-SP, stroke-prone spontaneously hypertensive rats; WKY, Wistar-Kyoto.

Values are mean \pm s.e.m. ${ }^{* *} P<0.01$ vs. placebo. 

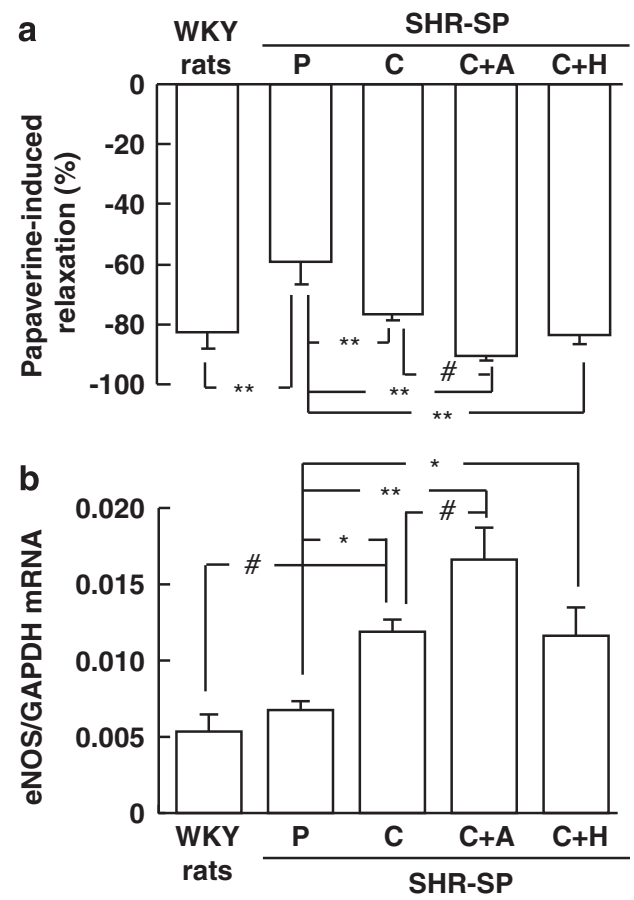

Figure 2 Acetylcholine-induced vascular relaxation in noradrenalineprecontracted carotid arteries in WKY rats and placebo (P)-, candesartan (C)-, candesartan plus amlodipine $(\mathrm{C}+\mathrm{A})$ - and candesartan plus HCTZ $(\mathrm{C}+\mathrm{H})$ treated SHR-SP (a). Gene expression of endothelial nitric oxide synthase (eNOS) in aortas obtained from the WKY rats and placebo (P)-, candesartan (C)-, candesartan plus amlodipine ( $\mathrm{C}+\mathrm{A})$ - and candesartan plus $\mathrm{HCTZ}(\mathrm{C}+\mathrm{H})-$ treated SHR-SP (b). ${ }^{*} P<0.05$ and ${ }^{* *} P<0.01$ vs. placebo-treated SHR-SP. ${ }^{\#} P<0.05$ vs. candesartan-treated SHR-SP.

significantly lower in the placebo-treated SHR-SP than in the WKY rats and was significantly greater in all candesartan-, candesartan plus amlodipine- and candesartan plus HCTZ-treated SHR-SP than in the placebo-treated SHR-SP (Figure 2a). Of note, vascular relaxation was significantly greater in the candesartan plus amlodipine-treated SHRSP than in the candesartan-treated SHR-SP, but no significant differences were found between the candesartan- and the candesartan plus HCTZ-treated SHR-SP (Figure 2a).

The eNOS gene expression in the aorta tended to be higher in the placebo-treated SHR-SP than in the WKY rats (Figure 2b). eNOS gene expression was significantly higher in all candesartan-, candesartan plus amlodipine- and candesartan plus HCTZ-treated SHR-SP than in the placebo-treated SHR-SP, and it was significantly higher in the candesartan plus amlodipine-treated SHR-SP than in the candesartantreated SHR-SP, but there were no significant differences between the candesartan plus HCTZ-treated SHR-SP and those treated with candesartan alone (Figure 2b).

Gene expressions of NADPH oxidase subunits in the aorta Gene expressions of the NADPH oxidase subunits p22 phox, gp91 ${ }^{\text {phox }}$, NOX1 and NOX4 in the aorta were significantly increased in the placebo-treated SHR-SP compared with the WKY rats (Figure 3). All gene expressions were significantly lower in the candesartan-, candesartan plus amlodipine- and candesartan plus HCTZ-treated SHR-SP than in the placebo-treated SHR-SP, but there were no significant differences among the monotherapy and combination therapy groups (Figure 3).
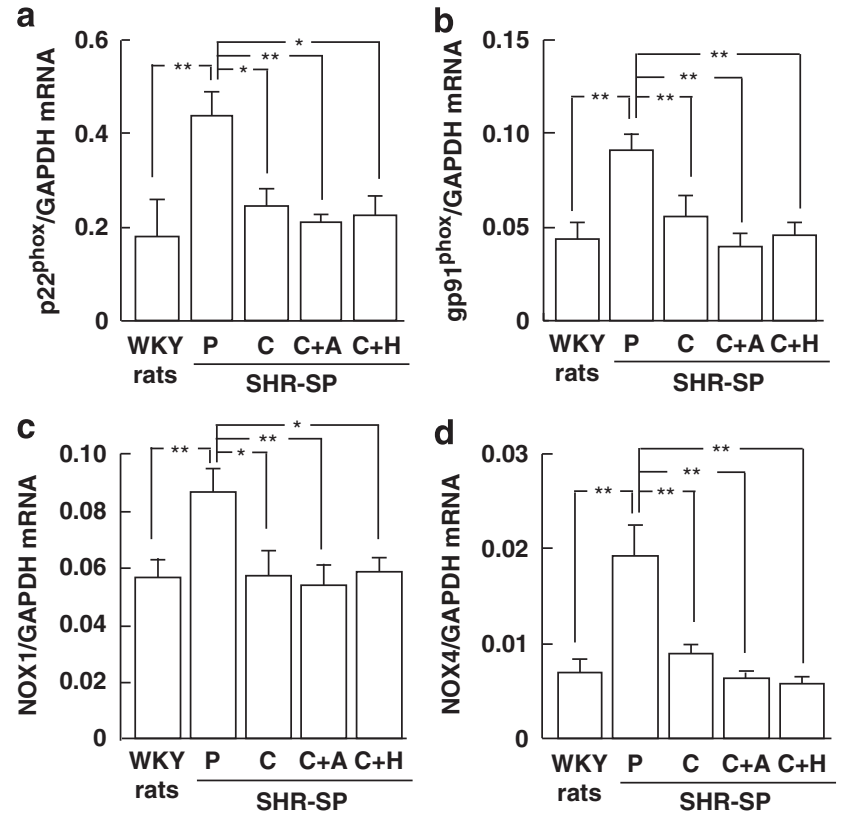

Figure 3 Gene expressions of p22 phox (a), gp91phox (b), NOX1 (c) and NOX4 (d) in aortas obtained from WKY rats and placebo (P)-, candesartan (C)-, candesartan plus amlodipine $(\mathrm{C}+\mathrm{A})$ - and candesartan plus $\mathrm{HCTZ}(\mathrm{C}+\mathrm{H})$ treated SHR-SP. ${ }^{*} P<0.05$ and ${ }^{* *} P<0.01$ vs. placebo-treated SHR-SP.

\section{SOD activity and gene expression in the aorta}

SOD activity in the aorta was significantly lower in the placebo-treated SHR-SP than in the WKY rats (Figure 4a). There was no significant difference in SOD activity between the placebo- and candesartantreated SHR-SP or between the placebo- and candesartan plus HCTZtreated SHR-SP. However, SOD activity was significantly higher in the candesartan plus amlodipine-treated SHR-SP than in the placebotreated SHR-SP (Figure 4a).

copper/zinc-containing SOD gene expression in the aorta was not significantly different among the groups (Figure $4 \mathrm{~b}$ ). Mn-SOD gene expression, however, was significantly lower in the placebo-treated SHR-SP than in the WKY rats, but it was significantly higher in the candesartan plus amlodipine-treated SHR-SP than in the placebotreated SHR-SP (Figure 4c). There were no significant differences among the placebo-, candesartan- and candesartan plus HCTZtreated SHR-SP. Although extracellular SOD gene expression was not significantly different between the WKY rats and the placebotreated SHR-SP, it was significantly higher in the candesartan plus amlodipine-treated SHR-SP than in the placebo-treated SHR-SP (Figure 4d).

\section{Immunohistochemistry of 4-HNE and MDA levels in the aorta} To evaluate the products of oxidative stress, the 4-HNE-positive area in the media of the aorta was evaluated (Figure $5 \mathrm{a}$ ). This area was small in the WKY rats, but was much larger in the placebo-treated SHR-SP. Although 4-HNE-positive areas were also observed in the candesartan-, candesartan plus amlodipine- and candesartan plus HCTZ-treated SHR-SP, they were clearly smaller than in the placebo-treated SHR-SP. The ratio of the 4-HNE-positive area to the total area in the media of the aorta was significantly higher in the placebo-treated SHR-SP than in the WKY rats (Figure 5b). Significant attenuation in the ratio was observed in the candesartan-, candesartan plus amlodipine- and candesartan plus HCTZ-treated SHR-SP 

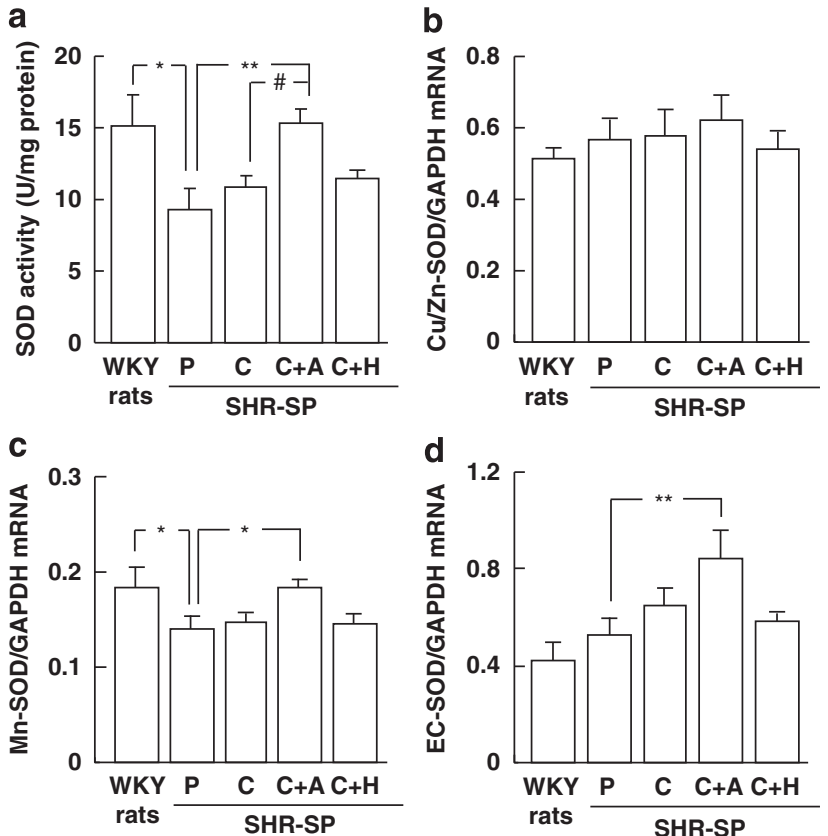

Figure 4 SOD activities in aortas obtained from WKY rats and placebo (P)-, candesartan (C)-, candesartan plus amlodipine $(\mathrm{C}+\mathrm{A})$ - and candesartan plus HCTZ $(\mathrm{C}+\mathrm{H})$-treated SHR-SP (a). Gene expressions of copper/ zinc-containing SOD (Cu/Zn-SOD) (b), manganese superoxide dismutase (Mn-SOD) (c) and extracellular SOD (EC-SOD) (d) in aortas obtained from WKY rats and placebo (P)-, candesartan (C)-, candesartan plus amlodipine $(\mathrm{C}+\mathrm{A})$ - and candesartan plus HCTZ $(\mathrm{C}+\mathrm{H})$-treated SHR-SP. ${ }^{*} P<0.05$ and ${ }^{*} P<0.01$ vs. placebo-treated SHR-SP. ${ }^{\#} P<0.05$ vs. candesartan-treated SHR-SP. compared with the placebo-treated SHR-SP (Figure 5b). Furthermore, the ratio was significantly lower in the candesartan plus amlodipinetreated SHR-SP than in the candesartan-treated SHR-SP, but no significant difference between the candesartan- and candesartan plus HCTZ-treated SHR-SP was observed (Figure 5b).

The MDA level in the aorta was significantly higher in the placebotreated SHR-SP than in the WKY rats (Figure 5c). Significant attenuation in the MDA level was observed in the candesartan-, candesartan plus amlodipine- and candesartan plus HCTZ-treated SHR-SP compared with the placebo-treated SHR-SP (Figure 5c). A significant attenuation of MDA level was also observed in the candesartan plus amlodipine-treated SHR-SP compared with the candesartan-treated SHR-SP (Figure 5c).

\section{Activity and gene expression of ACE in the aorta}

ACE activity in the aorta was significantly higher in the placebotreated SHR-SP than in the WKY rats, and a vascular ACE gene expression was significantly augmented in the placebo-treated SHR-SP compared with the WKY rats (Figure 6). Both the activity and gene expression of ACE were significantly lower in the candesartan plus amlodipine-treated SHR-SP than in the placebo-treated SHR-SP, but there were no significant differences among the placebo-, candesartan- and candesartan plus HCTZ-treated SHR-SP (Figure 6).

\section{DISCUSSION}

The present study aimed to evaluate the vascular protective effect of combination therapy with $\mathrm{ARB}$ plus $\mathrm{CCB}$ or $\mathrm{ARB}$ plus a diuretic, as both combination therapies have been shown to have a greater hypotensive effect than ARB monotherapy. In this study, the SBP in 8 -week-old SHR-SP was shown to be about $180 \mathrm{~mm} \mathrm{Hg}$ before treatment, but it increased to more than $230 \mathrm{~mm} \mathrm{Hg}$ in the placebo-treated

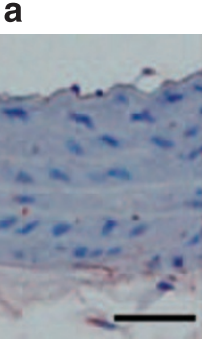

WKY rats

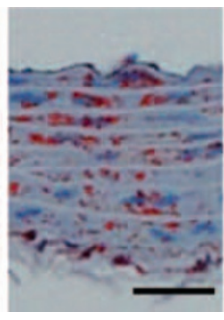

$\mathbf{P}$

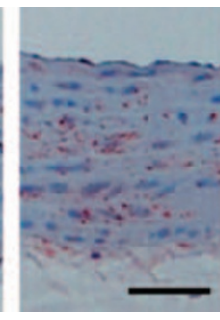

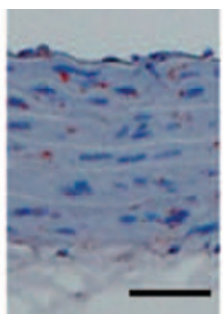

$\mathrm{C}+\mathrm{A}$

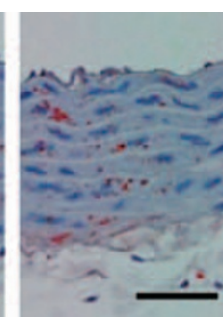

$\mathrm{C}+\mathrm{H}$ b

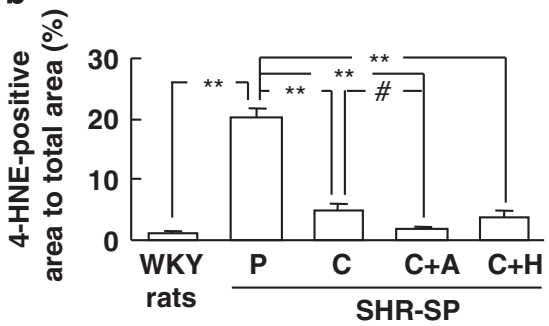

SHR-SP

C

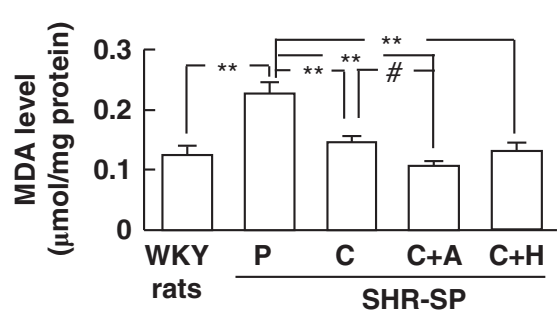

Figure 5 Typical photographs of anti-4-hydroxy-2-nonenal (4-HNE) antibody-stained aortas in a WKY rat and placebo-, candesartan-, candesartan plus amlodipine- and candesartan plus HCTZ-treated SHR-SP (a). Scale bars show $50 \mu \mathrm{m}$ (a). Ratios of anti-4-HNE-stained area to total area in the WKY rats and placebo (P)-, candesartan (C)-, candesartan plus amlodipine (C+A)- and candesartan plus HCTZ (C+H)-treated SHR-SP (b). malondialdehyde (MDA) levels in aortas obtained from the WKY rats and placebo (P)-, candesartan (C)-, candesartan plus amlodipine (C+A)- and candesartan plus $\mathrm{HCTZ}(\mathrm{C}+\mathrm{H})$-treated SHR-SP (c). ${ }^{*} P<0.01$ vs. placebo-treated SHR-SP. ${ }^{\#} P<0.05$ vs. candesartan-treated SHR-SP. 

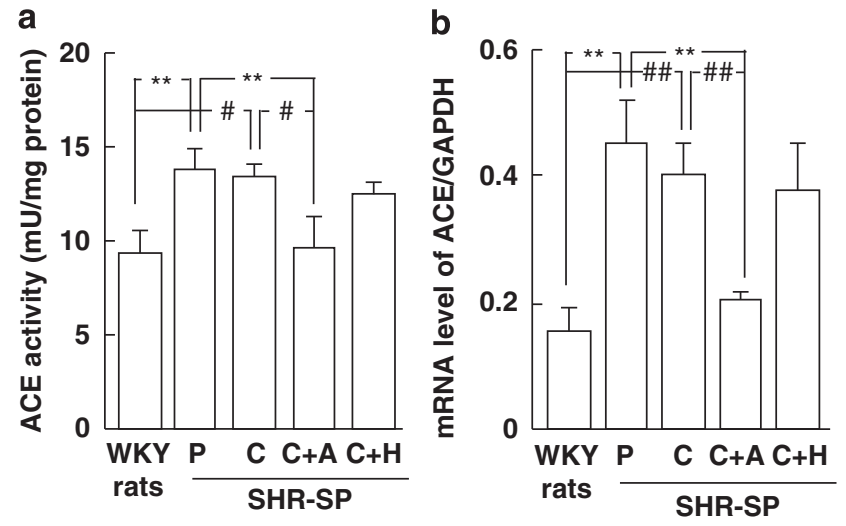

Figure 6 Angiotensin-converting enzyme (ACE) activities in aortas obtained from WKY rats and placebo (P)-, candesartan (C)-, candesartan plus amlodipine $(\mathrm{C}+\mathrm{A})$ - and candesartan plus HCTZ $(\mathrm{C}+\mathrm{H})$-treated SHR-SP (a). Gene expressions of ACE in aortas obtained from the WKY rats and placebo (P)-, candesartan (C)-, candesartan plus amlodipine $(C+A)$ - and candesartan plus HCTZ $(\mathrm{C}+\mathrm{H})$-treated SHR-SP (b). ${ }^{* *} P<0.01$ vs. placebo-treated SHRSP. ${ }^{\#} P<0.05$ and ${ }^{\#} P<0.01$ vs. candesartan-treated SHR-SP.

group after the last treatment. In the candesartan-treated group, SBP was significantly lowered to $186 \mathrm{~mm} \mathrm{Hg}$. In the candesartan plus amlodipine- and candesartan plus HCTZ-treated groups, SBP was further significantly lowered to 156 and $150 \mathrm{~mm} \mathrm{Hg}$, respectively, although there was no significant difference between the two groups. However, acetylcholine-induced vascular relaxation was significantly attenuated by monotherapy and both combination therapies, and greater attenuation than with monotherapy was observed with candesartan and amlodipine combination therapy. The vascular relaxation with candesartan and HCTZ combination therapy tended to be lower than with candesartan monotherapy, but no significant difference between these therapies was found. This suggests that combination therapy with candesartan and amlodipine could have a greater vascular protective effect than combination therapy with candesartan and HCTZ because equal, additive hypotensive effects were observed with these combination therapies.

In the present study, the sodium nitroprusside-induced vascular relaxation was not significantly different among all groups (data not shown), and the endothelial dysfunction could be directly affected by nitric oxide bioavailability. However, the reduced nitric oxide bioavailability may be related to increased oxidative stress rather than decreased eNOS gene expression. In the present study, we did not observe a significant difference in eNOS gene expression between the WKY rats and placebo-treated SHR-SP. In the present study, as in previous studies, eNOS gene expression tended to be higher in SHRSP than in WKY rats, and it was not commensurate with endothelial dysfunction. ${ }^{17,19}$ Therefore, factors in addition to eNOS gene expression may be related to endothelial dysfunction in SHR-SP. However, we also observed that the eNOS gene expression was significantly higher in the monotherapy and the combination therapy groups than in the placebo group, but the degree of expression was significantly greater with candesartan plus amlodipine combination therapy than with candesartan monotherapy. The greater improvement of endothelial dysfunction with the candesartan plus amlodipine combination therapy may be partly due to the combination therapy's augmentation of eNOS gene expression.

The greater vascular protective effect from combination therapy with candesartan plus amlodipine compared with candesartan plus HCTZ might be related to the degree of oxidative stress attenuation.
Vascular gene expressions of NADPH oxidase subunits were significantly augmented in the placebo-treated group. Various stimuli, such as angiotensin II and stretch, acutely activate the NADPH oxidase in vascular smooth muscle and endothelial cells. ${ }^{20}$ Furthermore, pathophysiological stimuli such as angiotensin II can also increase the expression of several NADPH oxidase subunits, further promoting reactive oxidative species (ROS). ${ }^{21}$ An increase in NADPH oxidase activity is closely related to oxidative stress caused by angiotensin II in the vascular tissue of hypertensive rats, and the oxidative stress caused by NADPH oxidase has an important role in the development and progression of vascular remodeling. ${ }^{2-24}$ In the present study, the gene expressions of NADPH oxidase subunits in SHR-SP were strongly attenuated by candesartan monotherapy, and no significant additional attenuation was observed with combination therapies. The dose of candesartan used in the present study might have produced a sufficient attenuating effect of gene expressions of NADPH oxidase subunits. A recent study reported that ARB and CCB combination therapy significantly attenuated vascular ROS promotion in cuffinjured arteries when compared with ARB monotherapy in mice, although ROS promotion was not attenuated by ARB monotherapy. ${ }^{15}$ In that study, not all ARB monotherapy and ARB and CCB combination therapy doses affected the blood pressure significantly when compared with the control group. ${ }^{15}$ Therefore, the additional attenuation of ROS promotion from each combination therapy might be limited when the ARB monotherapy dose that showed a significant hypotensive effect was used because strong attenuation of gene expressions of NADPH oxidase subunits was observed even with ARB monotherapy.

On the other hand, vascular SOD activity was significantly attenuated in the placebo-treated SHR-SP when compared with the WKY rats, but only candesartan plus amlodipine combination therapy produced significant SOD activity augmentation in SHR-SP. CCBs, including amlodipine and nifedipine, has been shown to augment SOD levels in cultured endothelial cells. ${ }^{25,26}$ Superoxide anion produced by NADPH oxidase is known to be scavenged by an antioxidant enzyme, SOD, and SOD activity augmentation is known to diminish vascular oxidative stress as part of the antioxidant defense system. ${ }^{27,28}$ Fukuo et al. ${ }^{26}$ reported that nifedipine induced $\mathrm{Mn}$-SOD gene expression in vascular smooth muscle cells. In the present study, candesartan and amlodipine combination therapy showed significant augmentation of Mn-SOD and extracellular SOD gene expressions, but other therapies did not. The upregulation of Mn-SOD and extracellular SOD gene expressions by candesartan and amlodipine combination therapy may be partially involved in vascular SOD activity augmentation. Moreover, the vascular MDA level and 4-HNE-positive area, both of which are products of lipid peroxidation, were also better attenuated by candesartan and amlodipine combination therapy than candesartan monotherapy, but they were not affected by candesartan and HCTZ combination therapy. Endothelial dysfunction in hypertension is characterized by the reduced bioavailability of nitric oxide, and reduced nitric oxide bioavailability is involved in augmentation with superoxide anion. ${ }^{29}$ An imbalance between oxidants and antioxidants, resulting from excessive ROS production and an insufficient antioxidant defense system, promotes endothelial dysfunction. ${ }^{30,31}$ Therefore, the superior effect of candesartan plus amlodipine combination therapy compared with candesartan monotherapy might be related to the augmentation of vascular SOD activity by the combination therapy.

In the present study, significant vascular ACE activity augmentation was observed in the placebo-treated SHR-SP when compared with the WKY rats. Previous reports have shown that vascular ACE activity was 
increased in SHR-SP, and the same phenomenon was observed in the present study. ${ }^{4,5}$ The increased ACE activity might augment bradykinin degradation along with angiotensin II formation, thereby inducing additional oxidative stress and further impairing endothelial function. Surprisingly, in the present study, candesartan plus amlodipine combination therapy attenuated increased vascular ACE activity and its gene expression in SHR-SP, but neither candesartan monotherapy nor candesartan plus HCTZ combination therapy had the same effect. We did not confirm whether amlodipine monotherapy attenuated ACE activity in the SHR-SP in the present study; however, Toba et al. ${ }^{32}$ demonstrated that amlodipine, but not hydralazine, attenuated the increase of both vascular ACE activity and its gene expression in $N^{\omega}$-nitro-L-arginine methyl ester-induced hypertensive rats, despite producing the same hypotensive effects as amlodipine and hydralazine. In $N^{\omega}$-nitro-L-arginine methyl ester-induced hypertensive rats, Usui et al. ${ }^{33}$ reported that antioxidant drugs attenuated not only the increased oxidative stress, but also the induced vascular ACE activity. Kataoka et al. ${ }^{34}$ also demonstrated that amlodipine significantly attenuated $N^{\omega}$-nitro-L-arginine methyl ester-induced increases in oxidative stress and vascular ACE activity in rats. Furthermore, in cholesterol-fed rabbits, amlodipine significantly attenuated aortic ACE activity and enhanced the SOD activity. ${ }^{35}$ These reports suggest that oxidative stress augmentation induces vascular ACE activity and that amlodipine may be useful for attenuating vascular ACE activity via the reduction of oxidative stress by SOD activity augmentation. We could not evaluate the angiotensin II levels in the vessels and did not determine whether candesartan and amlodipine combination therapy reduced vascular angiotensin II levels. Vascular angiotensin II levels have been related to vascular ACE activity in various experimental models. ${ }^{36,37}$ Therefore, the vascular protective effect of candesartan plus amlodipine combination therapy may involve reducing the vascular angiotensin II level. This needs to be clarified in a future study.

In conclusion, candesartan plus amlodipine combination therapy produced powerful oxidative stress reductions by attenuating NADPH oxidase and augmenting SOD. It also had a strong vascular protective effect in SHR-SP. Thus, adding amlodipine to candesartan monotherapy to produce an additive hypotensive effect may provide powerful vascular protection.

\section{CONFLICT OF INTEREST}

The authors declare no conflict of interest.

1 Griendling KK, Minieri CA, Ollerenshaw JD, Alexander RW. Angiotensin II stimulates $\mathrm{NADH}$ and NADPH oxidase activity in cultured vascular smooth muscle cells. Circ Res 1994; 74: 1141-1148.

2 Rajagopalan S, Kurz S, Munzel T, Tarpey M, Freeman BA, Griendling KK, Harrison DG. Angiotensin II-mediated hypertension in the rat increases vascular superoxide production via membrane NADH/-NAD(P)H oxidase activation. Contribution to alterations of vasomotor tone. J Clin Invest 1996; 97: 1916-1923.

3 Laursen JB, Rajagopalan S, Galis Z, Tarpey M, Freeman BA, Harrison DG. Role of superoxide in angiotensin II-induced but not catecholamine-induced hypertension. Circulation 1997; 95: 588-593.

4 Takai S, Jin D, Kimura M, Kirimura K, Sakonjo H, Tanaka K, Miyazaki M. Inhibition of vascular angiotensin-converting enzyme by telmisartan via the peroxisome proliferatoractivated receptor $\gamma$ agonistic property in rats. Hypertens Res 2007; 30: 1231-1237.

5 Takai S, Jin D, Ikeda H, Sakonjo H, Miyazaki M. Significance of angiotensin II receptor blockers with high affinity to angiotensin II type 1 receptors for vascular protection in rats. Hypertens Res 2009; 32: 853-860.

6 Yusuf S, Sleight P, Pogue J, Bosch J, Davies R, Dagenais G. Effects of an angiotensinconverting-enzyme inhibitor, ramipril, on cardiovascular events in high-risk patients. N Engl J Med 2000; 342: 145-153.

7 Mochizuki S, Dahlöf B, Shimizu M, Ikewaki K, Yoshikawa M, Taniguchi I, Ohta M, Yamada T, Ogawa K, Kanae K, Kawai M, Seki S, Okazaki F, Taniguchi M, Yoshida S, Tajima N, Jikei Heart Study group. Valsartan in a Japanese population with hypertension and other cardiovascular disease (Jikei Heart Study): a randomised, open-label, blinded endpoint morbidity-mortality study. Lancet 2007; 369: 1431-1439.
8 Turnbull F, Blood Pressure Lowering Treatment Trialists' Collaboration. Effects of different blood-pressure-lowering regimens on major cardiovascular events: results of prospectively-designed overviews of randomised trials. Lancet 2003; 362: 1527-1535.

9 Turnbull F, Neal B, Pfeffer M, Kostis J, Algert C, Woodward M, Chalmers J, Zanchetti A, MacMahon S, Blood Pressure Lowering Treatment Trialists' Collaboration. Blood pressure-dependent and independent effects of agents that inhibit the reninangiotensin system. J Hypertens 2007; 25: 951-958.

10 Ogihara T, Kikuchi K, Matsuoka H, Fujita T, Higaki J, Horiuchi M, Imai Y, Imaizumi T, Ito S, Iwao H, Kario K, Kawano Y, Kim-Mitsuyama S, Kimura G, Matsubara H, Matsuura H, Naruse M, Saito I, Shimada K, Shimamoto K, Suzuki H, Takishita S, Tanahashi N, Tsuchihashi T, Uchiyama M, Ueda S, Ueshima H, Umemura S, Ishimitsu T, Rakugi H, Japanese Society of Hypertension Committee. The Japanese Society of Hypertension Guidelines for the Management of Hypertension (JSH 2009). Hypertens Res 2009; 32: 3-107.

11 Dahlöf B, Sever PS, Poulter NR, Wedel H, Beevers DG, Caulfield M, Collins R, Kjeldsen SE, Kristinsson A, Mclnnes GT, Mehlsen J, Nieminen M, O'Brien E, Ostergren, ASCOT Investigators. Prevention of cardiovascular events with an antihypertensive regimen of amlodipine adding perindopril as required vs. atenolol adding bendroflumethiazide as required, in the Anglo-Scandinavian Cardiac Outcomes Trial-Blood Pressure Lowering Arm (ASCOT-BPLA): a multicentre randomised controlled trial. Lancet 2005; 366: 895-906.

12 Dahlöf B, Devereux RB, Kjeldsen SE, Julius S, Beevers G, de Faire U, Fyhrquist F, Ibsen H, Kristiansson K, Lederballe-Pedersen O, Lindholm LH, Nieminen MS, Omvik P, Oparil S, Wedel H, LIFE Study Group. Cardiovascular morbidity and mortality in the Losartan Intervention For Endpoint reduction in hypertension study (LIFE): a randomised trial against atenolol. Lancet 2002; 359: 995-1003.

13 Kim-Mitsuyama S, Izumi Y, Izumiya Y, Yoshida K, Yoshiyama M, Iwao H. Additive beneficial effects of the combination of a calcium channel blocker and an angiotensin blocker on a hypertensive rat-heart failure model. Hypertens Res 2004; 27: 771-779.

14 Jinno T, Iwai M, Li Z, Li JM, Liu HW, Cui TX, Rakugi H, Ogihara T, Horiuchi M. Calcium channel blocker azelnidipine enhances vascular protective effects of $\mathrm{AT}_{1}$ receptor blocker olmesartan. Hypertension 2004; 43: 263-269.

15 Inaba S, Iwai M, Tomono Y, Senba I, Furuno M, Kanno H, Okayama H, Mogi M, Higaki J, Horiuchi M. Prevention of vascular injury by combination of an $\mathrm{AT}_{1}$ receptor blocker, olmesartan, with various calcium antagonists. Am J Hypertens 2009; 22: 145-150.

16 Takai S, Jin D, Ohzu M, Tanaka K, Miyazaki M. Chymase inhibition provides pancreatic islet protection in hamsters with streptozotocin-induced diabetes. J Pharmacol Sci 2009; 110: 459-465.

17 Takai S, Kirimura K, Jin D, Muramatsu M, Yoshikawa K, Mino Y, Miyazaki M. Significance of angiotensin II receptor blocker lipophilicities and their protective effect against vascular remodeling. Hypertens Res 2005; 28: 593-600.

18 Dowell FJ, Martin W, Dominiczak AF, Hamilton CA. Decreased basal despite enhanced agonist-stimulated effects of nitric oxide in 12-week-old stroke-prone spontaneously hypertensive rat. Eur J Pharmacol 1999; 379: 175-182.

19 Tanabe A, Naruse M, Adachi C, Seki T, Yoshimoto T, Takagi S, Naruse K, Takano K. Hydralazine decreases blood pressure and endothelin-1 mRNA expression in tissues but not cardiac weight in SHR-SP/Izm rats. J Cardiovasc Pharmacol 2000; 36(5 Suppl 1): S176-S178.

20 Mueller CF, Laude K, McNally JS, Harrison DG. ATVB in focus: redox mechanisms in blood vessels. Arterioscler Thromb Vasc Biol 2005; 25: 274-278.

21 Lasségue B, Clempus RE. Vascular NAD(P)H oxidases: specific features, expression, and regulation. Am J Physiol Regul Integr Comp Physiol 2003; 285: R277-R297.

22 Seshiah PN, Weber DS, Rocic P, Valppu L, Taniyama Y, Griendling KK. Angiotensin II stimulation of $\mathrm{NAD}(\mathrm{P}) \mathrm{H}$ oxidase activity: upstream mediators. Circ Res 2002; 91 : 406-413.

23 Fukui T, Ishizaka N, Rajagopalan S, Laursen JB, Capers IV Q, Taylor WR, Harrison DG, de Leon H, Wilcox JN, Griendling KK. p22 ${ }^{\text {phox }}$ mRNA expression and NADPH oxidase activity are increased in aortas from hypertensive rats. Circ Res 1997; 80: 45-51.

24 Hamilton CA, Brosnan MJ, AI-Benna S, Berg G, Dominiczak AF. NAD(P)H oxidase inhibition improves endothelial function in rat and human blood vessels. Hypertension 2002; 40: 755-762.

25 Mak IT, Boehme P, Weglicki WB. Antioxidant effects of calcium channel blockers against free radical injury in endothelial cells. Correlation of protection with preservation of glutathione levels. Circ Res 1992; 70: 1099-1103.

26 Fukuo K, Yang J, Suzuki T, Kaimoto T, Takemura Y, Yasuda O, Suhara T, Sato $N$, Ogihara T. Nifedipine upregulates manganese superoxide dismutase expression in vascular smooth muscle cells via endothelial cell-dependent pathways. Hypertens Res 2003; 26: 503-508

27 Lum H. Roebuck KA. Oxidant stress and endothelial cell dysfunction. Am J Physiol Cell Physiol 2001; 280: C719-C741.

28 Guzik TJ, Harrison DG. Vascular NADPH oxidases as drug targets for novel antioxidant strategies. Drug Discov Today 2006; 11: 524-533.

29 Cohen RA, Tong X. Vascular oxidative stress: the common link in hypertensive and diabetic vascular disease. J Cardiovasc Pharmacol 2010; 55: 308-316.

30 Cifuentes ME, Rey FE, Carretero OA, Pagano PJ. Upregulation of p67 phox and gp9 $1^{\text {phox }}$ in aortas from angiotensin Il-infused mice. Am J Physiol Heart Circ Physiol 2000; 279: $\mathrm{H} 2234-\mathrm{H} 2240$.

31 Fortu ño A, San José G, Moreno MU, Beloqui O, Díez J, Zalba G. Phagocytic NADPH oxidase overactivity underlies oxidative stress in metabolic syndrome. Diabetes 2006; 55: 209-215.

32 Toba H, Nakagawa Y, Miki S, Shimizu T, Yoshimura A, Inoue R, Asayama J, Kobara M, Nakata T. Calcium channel blockades exhibit anti-inflammatory and antioxidative effects by augmentation of endothelial nitric oxide synthase and the inhibition of angiotensin converting enzyme in the $N^{G}$-nitro-L-arginine methyl ester-induced 
hypertensive rat aorta: vasoprotective effects beyond the blood pressure-lowering effects of amlodipine and manidipine. Hypertens Res 2005; 28: 689-700.

33 Usui M, Egashira K, Kitamoto S, Koyanagi M, Katoh M, Kataoka C, Shimokawa H, Takeshita A. Pathogenic role of oxidative stress in vascular angiotensin-converting enzyme activation in long-term blockade of nitric oxide synthesis in rats. Hypertension 1999; 34: 546-551.

34 Kataoka C, Egashira K, Ishibashi M, Inoue S, Ni W, Hiasa K, Kitamoto S, Usui M, Takeshita A. Novel anti-inflammatory actions of amlodipine in a rat model of arteriosclerosis induced by long-term inhibition of nitric oxide synthesis. Am J Physiol Heart Circ Physiol 2004; 286: H768-H774.
35 Turgan N, Habif S, Kabaroalu CG, Mutaf I, Ozmen D, Bayindir O, Uysal A. Effects of the calcium channel blocker amlodipine on serum and aortic cholesterol, lipid peroxidation, antioxidant status and aortic histology in cholesterol-fed rabbits. J Biomed Sci 2003; 10: 65-72.

36 Morishita R, Higaki J, Miyazaki M, Ogihara T. Possible role of the vascular reninangiotensin system in hypertension and vascular hypertrophy. Hypertension 1992; 19(2 Suppl): ||62-II67.

37 Miyazaki M, Sakonjo H, Takai S. Anti-atherosclerotic effects of an angiotensin converting enzyme inhibitor and an angiotensin II antagonist in Cynomolgus monkeys fed a high-cholesterol diet. Br J Pharmacol 1999; 128: 523-529. 